\title{
Growth and Yield of Soybean as a Response of the Fertilization of NPK Compound Produced with Spent and Deoiled Bleaching Earth Filler
}

\author{
Radinal Arief Sinaga, Budiastuti Kurniasih and Eka Tarwaca Susila Putra* \\ Department of Agronomy, Faculty of Agriculture, Universitas Gadjah Mada, Yogyakarta, Indonesia \\ *Corresponding author: eka.tarwaca.s@ugm.ac.id
}

\begin{abstract}
Spent Bleaching Earth (SBE) is a by-product of the refining of Crude Palm Oil (CPO) into cooking oil which is classified as hazardous and toxic materials waste. SBE has the potential to be used as a filler in the production of NPK fertilizer. This study aims to compare the effect of SBE and Deoiled Bleaching Earth (DBE) as the replacement of clay mineral, which is expected to have the same effect as the control treatment in terms of the leaf area, total dry weight, plant height and yield of plant. This experiment used a one-factor Randomized Complete Block Design (RCBD) with three replicates. The treatments of filler in NPK fertilizer were $10 \%$ clay minerals, NPK with $5 \%$ clay mineral $+5 \%$ SBE filler and NPK with $5 \%$ clay mineral $+5 \%$ DBE filler. Fertilizer was given twice, ie when the plant was 14 days after planting (DAP) as much as $2 \mathrm{~g}$ polybag $^{-1}$ and age $35 \mathrm{DAP}$ as much as $3 \mathrm{~g}$ polybag ${ }^{-1}$ at each treatment. The results showed that the application of NPK fertilization with 5\% clay mineral $+5 \%$ SBE filler and NPK fertilization with 5\% clay mineral +5\% DBE filler had the same effect as NPK fertilization with $10 \%$ clay mineral filler on leaf area, total dry weight, plant height and yield of plant. SBE and DBE can be used as substituties for clay mineral in NPK fertilizer production.
\end{abstract}

Keywords: deoiled bleaching earth; NPK; soybean; spent bleaching earth

Cite this as: Sinaga, R. A., Kurniasih, B., \& Putra, E. T. S. (2021). Growth and Yield of Soybean as a Response of the Fertilization of NPK Compound Produced with Spent and Deoiled Bleaching Earth Filler. Caraka Tani: Journal of Sustainable Agriculture, 36(1), 11-19. doi: http://dx.doi.org/10.20961/carakatani.v36i1.35682

\section{INTRODUCTION}

Soybean is a popular food crop in Indonesia. According to PUSDATIN KEMENTAN (2018), soybean production in 2017 was 538,728 tons, then in 2018 increased to 982,598 tons. This is in line with the increase in the soybean harvest area, which was formerly 355,799 ha in 2017 , increased to 680,373 ha in 2018. One of the intensive efforts to increase soybean production is to optimize the existing land area by using superior seeds, good soil tillage and the proper use of fertilizer.

Plants need enough macro and micronutrients for their growing and developing. Fertilization must be applied to meet the needs of nutrients for plants, so they can grow, develop and produce well. Fertilizers contain nutrients needed by plants, both macro and micronutrients. Fertilizer can also provide the certain nutrients in the soil so that it meets the needs of plants for nutrients (Adileksana et al., 2020). Nutrients of N, P and $\mathrm{K}$ are essentially required by plants in large amounts. Nitrogen is needed for protein synthesis, leaf development and supports metabolic processes such as photosynthesis. Phosphorus plays a role in stimulating root growth and the formation of a good root system in young plants, as a constituent of cell nuclei (nucleic acids), fats and proteins. Potassium plays a role in helping the synthesis of proteins and carbohydrates, increasing plant resistance to pests

\footnotetext{
* Received for publication November 19, 2019

Accepted after corrections October 9, 2020
} 
and diseases and improving the quality of crop yields (Rauf et al., 2000).

In addition to NPK, soybeans also need a supply of micronutrients. Micronutrients are obtained through packaging fertilizers directly or indirectly through natural processes and some sources from industrial organic waste. The waste has the potential to penetrate the soil and then absorbed by plants. A positive plant response arises if the nutrient or metal dosage contained in the waste is sufficient, but if excessive, the plant experiences toxicity and growth retardation (Loh et al., 2013).

The oil palm (Elaeis guineensis Jacq.) is a prime and leading plantation commodity in Indonesia. The plants whose main products are Crude Palm Oil (CPO) and Palm Kernel Oil (PKO) have high economic values and one of the country's biggest foreign exchange earners compared to other plantation commodities (Ermawati and Saptia, 2013). One of the products from CPO is cooking oil. Cooking oil is the output of purification from CPO using bleaching earth, namely bentonite (Park et al., 2004; Kheang et al., 2006). This purification process aims to eliminate metal content, carotene dyes, moisture, insoluble substances, or colloidal substances such as resins, gums, proteins and phosphatides in CPO so that the oil becomes clearer (Soda et al., 2006; Hussin et al., 2011). Secondary product of this purification is SBE. It's resulting in 1\% of weight of refined CPO (Embrandiri et al., 2012; Loh et al., 2013; Fahmi et al., 2014; Kamilah et al., 2018).

In 2018 Indonesia's CPO production was 43 million tons; hence, the Spent Bleaching Earth (SBE) produced was 430,000 tons (Boey et al., 2011; Loh et al., 2015). Referring to the Government Regulation of the Republic of Indonesia No 101 of 2014, SBE is included in the list of B3 waste from specific sources specifically with the B413 waste code, where the source of waste originates from the oleochemical and/or processing of animal or vegetable oil with hazard category 2 because it contains metal residues weight. The SBE also contained oil residues, the remaining of the CPO purification process.

Many studies have proven that SBE waste can be reused; for example as animal feed ( $\mathrm{Ng}$ et al., 2006), as a raw material for making fuel briquettes (Suhartini et al., 2011), as a substitute for sand in making concrete (Sumarno et al., 2017) and as a raw material for making cement and bricks
(Beshara and Cheeseman, 2014; Eliche-Quesada and Corpas-Iglesias, 2014). The use of SBE as a bio-product such as fertilizer provides added value for waste reduction, reduces production cost for oil palm plantation and improves environmental health to support sustainable agriculture (Ofori-Boateng and Lee, 2013). However, its use in agriculture is still limited. Limitations on the use of SBE occur due to the high oil content and the alleged presence of heavy metals in the material. Those limitations have the potential to inhibit the rate of oxygen diffusion from the atmosphere to the ground. There is a material extracted further to reduce the oil content in SBE. The new material extracted from $\mathrm{SBE}$ is called Deoiled Bleaching Earth (DBE).

The presence of SBE and DBE is thought to cause heavy metal toxicity in plants. Heavy metal poisoning causes soybean plants stunted and brown spots appear on the leaves, which gradually stop the photosynthesis process in plants. Toxicity due to heavy metals in soybean causes degradation of lipids, proteins, carbohydrates and nucleic acids, damaging cell metabolism and causing cell death in some cases (Fernando et al., 2013). Plants sign toxicity through receptors that trigger molecular signals that send signals to those that regulate the next system through ion channels, which indicates that the system of enzymes and proteins are disrupted (Ahmad et al., 2016).

Based on its characteristics, SBE has the potential to substitute clay as a filler material in the manufacture of NPK fertilizer. SBE itself comes from bentonite, so logically it thought to be similar to pure clay mineral in general NPK compound fertilizer. The use of SBE as an NPK filler is expected to be better if the oil concentration is reduced, known as DBE. The purpose of this study was to compare the effect of SBE and DBE as the replacement of clay mineral, which is expected to have the same effect as the control treatment in terms of the leaf area, total dry weight, plant height and yield of plant.

\section{MATERIALS AND METHOD}

The study was conducted in November 2018 - February 2019, at experimental farm Agrotechnology Innovation Center (AIC) of Universitas Gadjah Mada (UGM), Kalitirto, Sleman, Special Region of Yogyakarta, Indonesia with coordinate $7^{\circ} 47^{\prime} 54.5^{\prime \prime}$ South Latitude (SL), 
110 27'52.3" East Longitude (EL) and Plant Production Management Laboratory belongs to Faculty of Agriculture, Universitas Gadjah Mada, Yogyakarta, Indonesia. The study used a Randomized Complete Block Design (RCBD) with 3 blocks as replicates and 3 treatments were consisted of NPK fertilizer $(15: 15: 15)$ with $10 \%$ clay mineral filler (control), NPK fertilizer with $5 \%$ clay mineral $+5 \%$ SBE filler and NPK fertilizer with $5 \%$ clay mineral $+5 \%$ DBE filler. The treatments in each block used 12 plants as sampels, with a total of 108 plants. Polybag size was $50 \mathrm{~cm} \times 50 \mathrm{~cm}$.

The planting media used were regosol soil, obtained from the AIC UGM farmland, filled into polybags with a weight of $20 \mathrm{~kg}_{\text {polybag }}{ }^{-1}$. The soybean seeds of Grobogan variety were planted using direct seeding method and then thinning activities were carried out when the plants were 2 weeks after planting (WAP) by pulling out and leaving only one plant in each polybag. Plant care included watering every morning or evening by looking at the condition of plants in a polybag, then weeding was done by removing weeds manually which grew in the polybag and cleaning weeds in the study area. The application of treatment fertilizers were done twice when the plant was 14 DAP as much as $2 \mathrm{~g}^{\text {polybag }}{ }^{-1}$ and age $35 \mathrm{DAP}$ as much as $3 \mathrm{~g}^{\mathrm{g}} \mathrm{polybag}^{-1}$ each treatment (Rosi et al., 2018).

The observations included analysis of heavy metals in soil and kernel soybean using the Atomic Absorption Spect (AAS) method (Eviati and Sulaeman, 2009). The heavy metals concentration in soil was measured by extracting Diethylenetriamine Pentaacetic Acid (DTPA) which could dissolve metals ion in the form of chelate compound, then weighing $10 \mathrm{~g}$ of fine soil sampel $<2 \mathrm{~mm}$, adding $20 \mathrm{ml}$ of DTPA extracting solution, then shaken with a machine shake for 2 hours. The suspense was centrifuged to get clear extract and then each is measured with AAS device. The heavy metals concentration in kernel soybean was measured by extracting by wet ashing using a mixture of concentrated acids $\mathrm{HNO}_{3}$ and $\mathrm{HClO}_{4}$. Weighed 2,500 $\mathrm{g}$ of fine plant samples $<0.5 \mathrm{~mm}$ into the digest tube, added $5 \mathrm{ml}$ of concentrated nitric acid, left to stand overnight. The next day it was heated at $100^{\circ} \mathrm{C}$ for 1 hour 30 minutes, cooled and added $5 \mathrm{ml}$ of concentrated nitric acid and $1 \mathrm{ml}$ of concentrated perchloric acid. Then heated to $130^{\circ} \mathrm{C}$ for 1 hour, the temperature was increased again to $150^{\circ} \mathrm{C}$ for 2 hours 30 minutes (until the yellow steam ran out, if there were still yellow steam, the heating time was increased), after the yellow steam ran out the temperature was increased to $170^{\circ} \mathrm{C}$ for 1 hour, then the temperature was increased again to $200^{\circ} \mathrm{C}$ for 1 hour (until white vapor forms). The digestion was completed by the formation of a white precipitate or a clear solution of about $1 \mathrm{ml}$. The extract was cooled then diluted with ion-free water to $25 \mathrm{ml}$, then shaken until homogeneous, left overnight and then each was measured with AAS device. Other observations include plant height, leaf area, total dry weight, number of crop pods, crop pod weight, crop seed weight and 100 seed dry weight. The data were analyzed using analysis of variance with $\alpha=5 \%$, followed by LSD analysis, if there were significant differences between means of treatments.

\section{RESULTS AND DISCUSSION}

\section{Heavy metal content in the soil}

The addition of fertilizer containing heavy metals to the soils will have an impact on the increase heavy metals concentration. Table 1 shows the concentration of heavy metals in the soil before fertilization. Naturally, the earth already contains heavy metals from the parent rock. The concentration of heavy metals in the soil is generally lower than the critical limit, except $\mathrm{Ag}$ that exceeds the critical threshold. This indicates that the soil already contains heavy metals in it. This is necessary to determine the levels of heavy metals in soil after fertilization is carried out. Soil analysis is also carried out after harvest to determine the accumulation of heavy metals contained in the soil.

Table 2 shows that after harvest, the heavy metals $\mathrm{Cr}, \mathrm{Cu}, \mathrm{Pb}$ and $\mathrm{Zn}$ had increased, but their contents were still below the specified thresholds. The fertilizers with fillers of SBE and DBE are safe to use. NPK fertilizer with fillers contains some micronutrients. NPK fertilizer with fillers $\mathrm{SBE}$ and DBE are found to content copper $(\mathrm{Cu})$ and zinc (Zn) which are essential for plants. Essential micronutrients such as $\mathrm{Co}, \mathrm{Fe}, \mathrm{Mn}, \mathrm{Mo}$, $\mathrm{Cu}$ and $\mathrm{Zn}$ are required for plant growth and take part in redox reactions, electron transfers and other metabolic processes. Whereas non-essential metals of $\mathrm{Pb}, \mathrm{Cd}, \mathrm{Cr}$ and $\mathrm{Ag}$ are potentially to toxic plants (Rai et al., 2004). 
Table 1. The content of $\mathrm{Ag}, \mathrm{Cu}, \mathrm{Cr}, \mathrm{Pb}$ and $\mathrm{Zn}$ in the soil before fertilization

\begin{tabular}{ccc}
\hline Heavy metals & Concentrations in the soil $(\mathrm{ppm})$ & Degree* \\
\hline $\mathrm{Ag}$ & 9.17 & Exceeded the critical limit \\
$\mathrm{Cr}$ & 3.26 & Less than the critical limit \\
$\mathrm{Cu}$ & 2.80 & Less than the critical limit \\
$\mathrm{Pb}$ & 0.01 & Less than the critical limit \\
$\mathrm{Zn}$ & 0.10 & Less than the critical limit \\
\hline
\end{tabular}

Note: $*=$ Degree based on Eviati and Sulaeman (2009); Critical limit of Ag = 2 ppm; Cr $=75-100 \mathrm{ppm} ; \mathrm{Cu}=60$ 125 ppm; $\mathrm{Pb}=100-400$ ppm; $\mathrm{Zn}=70-400$ ppm

Table 2. The content of $\mathrm{Ag}, \mathrm{Cu}, \mathrm{Cr}, \mathrm{Pb}$ and $\mathrm{Zn}$ in the soil after harvest

\begin{tabular}{cccccc}
\hline \multirow{2}{*}{ Treatment } & \multicolumn{5}{c}{ Heavy metal content in the soil } \\
\cline { 2 - 6 } & $\mathrm{Ag}(\mathrm{ppm})$ & $\mathrm{Cu}(\mathrm{ppm})$ & $\mathrm{Cr}(\mathrm{ppm})$ & $\mathrm{Pb}(\mathrm{ppm})$ & $\mathrm{Zn}(\mathrm{ppm})$ \\
\hline NPK + clay mineral 10\% & 7.76 & 40.54 & 10.31 & $38.28 \mathrm{a}$ & 74.25 \\
NPK + clay mineral 5\% + SBE 5\% & 8.46 & 42.63 & 9.92 & $41.91 \mathrm{a}$ & 79.16 \\
NPK + clay mineral 5\% + DBE 5\% & 6.47 & 41.42 & 8.70 & $43.04 \mathrm{~b}$ & 88.90 \\
\hline CV $(\%)$ & 19.43 & 6.63 & 12.19 & 6.33 & 12.08 \\
\hline
\end{tabular}

Note: The number followed by different letters in the same column showed significant difference according to LSD $5 \%$

\section{Leaf area and total dry weight}

Leaves plays a role in photosynthetic process and translocate photosynthate. The leaf area determines the amount of sunlight energy captured and supports the process of photosynthesis. The broader the leaf area owned by the plant, the greater the light captured by the plant. Table 3 shows the leaf area affected by NPK fertilizer with different fillers. According to Widyaswari et al. (2017), the process of photosynthesis will be optimal if supported by broadleaf area, high chlorophyll content and high leaf area index. Leaf area describes the quality of leaves quantitatively in capturing sunlight as energy in the process of photosynthesis, where leaf area can affect the yield of plants.

Based on Table 3, Leaf area is not significantly different on all treatments. This is due to the development of leaf area in fillers of $5 \%$ clay mineral $+5 \%$ SBE and 5\% clay mineral $+5 \%$ DBE serve as well as $10 \%$ clay minerals filler. The sufficient macronutrients for plants will stimulate more carbohydrates formation and also stimulate leaf formation (Amanullah, 2015).

Table 3. Soybean leaf area and total dry weight at 40 DAP influenced by NPK fertilizer with different fillers

\begin{tabular}{ccc}
\hline Treatment & Leaf area $\left(\mathrm{cm}^{2}\right)$ & Total dry weight $(\mathrm{g})$ \\
\hline NPK + clay mineral 10\% & 3,799 & 26.39 \\
NPK + clay mineral 5\% + SBE 5\% & 4,418 & 26.28 \\
NPK + clay mineral 5\% + DBE 5\% & 3,963 & 24.43 \\
\hline CV $(\%)$ & 14.55 & 11.05 \\
\hline
\end{tabular}

The total dry weight of crop cultivation in the field is a result of the net accumulation of $\mathrm{CO}_{2}$ assimilation results throughout the life of the plant. $\mathrm{CO}_{2}$ assimilation is the result of the absorption of solar energy and due to solar radiation. Therefore, one of the factors that influence the total dry weight of the crop is the absorbed solar radiation and the efficient use of that energy for $\mathrm{CO}_{2}$ fixation (Gardner et al., 2008). Plant dry weight is used as an indicator that shows the amount of accumulation of assimilates during plant growth (Tunçtürk et al., 2011). The total dry weight is not significantly different on all treatments (Table 3). The dry weight of plant reflects the accumulation of organic compounds that are successfully synthesized from inorganic compounds, especially water and carbon dioxide. Nutrients that have been absorbed by the roots contribute to the increase in dry weight of plants (Putra et al., 2017).

Plant dry weight influenced by several factors including nutrient availability and net 
assimilation rate. The more carbohydrates which were formed and stored in the organ of the plant, the plants' dry weight will increase. Dry weight of plants determines the plants' biomass as photosynthetic products during the growing period. The availability of sufficient $P$ for plant affects the dry weight of plants. The higher available $\mathrm{P}$ for plants, it will be better for energy transfer and metabolism and it will also increase the plants' dry weight. The $\mathrm{P}$ element has an important role in the synthesis of ATP and NADPH as energy supplies (Mulyadi, 2012).

\section{Plant height}

Table 4 presents plant height at 3,5 and 7 WAP for all treatments of NPK with different fillers. All treatments were not significantly different for plant height at 3,5 and 7 WAP. Plant growth occurs because of the processes of cell division and cell elongation; where these processes require a lot of nutrients (Kastono, 2005). Plants absorbed nutrients and water as photosynthetic material and also the leaves can properly capture photons of sunlight and produce glucose and oxygen, which support the height growth of soybean plants (Jati et al., 2017).

Table 4. Effect of NPK compound fertilizer with different filler on plant height in soybeans aged 3,5 and 7 WAP

\begin{tabular}{cccc}
\hline \multirow{2}{*}{ Treatment } & \multicolumn{3}{c}{ Plant height $(\mathrm{cm})$} \\
\cline { 2 - 4 } & 3 WAP & 5 WAP & 7 WAP \\
\hline NPK + clay mineral 10\% & 19.17 & 44.43 & 57.54 \\
NPK + clay mineral 5\% + SBE 5\% & 20.04 & 46.43 & 60.88 \\
NPK + clay mineral 5\% + DBE 5\% & 19.28 & 44.28 & 61.58 \\
\hline CV $(\%)$ & 5.67 & 11.89 & 14.33 \\
\hline
\end{tabular}

\section{Yield of plant}

Plants need a balanced availability of nitrogen for the formation of amino acids and protein during the seed formation (Hanum, 2010) so that the pods are fully loaded (Permanasari et al., 2014). In addition, an increase in plant nitrogen will affect the rate of $\mathrm{P}$ absorption and consequently the rate of seed filling. Table 5 shows NPK fertilization with different filler on the number of crop pods, crop pod weight, crop seed weight and 100 seeds weight.

The yield components harvested in soybean are pods and seeds. The number of pods and pod weight were expected from soybean crop cultivation and have economic values. Based on Table 5, all treatments were not significantly different for yield and its components. Plants that are given NPK fertilization with $5 \%$ clay mineral $+5 \%$ SBE filler and NPK fertilization with 5\% clay mineral $+5 \%$ DBE filler were able to provide the nutrients supplies to assimilate in the form of pods and seeds which were as good as plants fertilized with NPK with $10 \%$ clay mineral filler (Purba et al., 2019).

Table 5. Effect of NPK fertilizer application with different filler on the number of crop pods, crop pod weight, crop seed weight and 100 seed dry weight

\begin{tabular}{ccccc}
\hline Treatment & $\begin{array}{c}\text { Number of } \\
\text { pods }\end{array}$ & $\begin{array}{c}\text { Pod weight } \\
\left(\mathrm{g} \mathrm{plant}^{-1}\right)\end{array}$ & $\begin{array}{c}\text { Kernel weight } \\
\left(\mathrm{g} \mathrm{plant}^{-1}\right)\end{array}$ & $\begin{array}{c}\text { Weight of 100 } \\
\text { seeds }(\mathrm{g})\end{array}$ \\
\hline NPK + clay mineral 10\% & 211 & 43.30 & 15.46 & 6.48 \\
NPK + clay mineral 5\% + SBE 5\% & 182 & 35.12 & 12.44 & 5.86 \\
NPK + clay mineral 5\% + DBE 5\% & 219 & 40.02 & 13.38 & 5.71 \\
\hline CV (\%) & 16.85 & 14.41 & 19.35 & 12.45 \\
\hline
\end{tabular}

\section{Heavy metal content in kernel soybean}

Table 6 presents heavy metal content in kernel soybean which applied NPK with different fillers. Soybean fertilized with NPK which fillers were SBE and DBE, are safe for consumption because the heavy metal contents were still below the specified thresholds. According to Zhuang et al.
(2013) the threshold for $\mathrm{Cu}$ is $20 \mathrm{ppm}, \mathrm{Cr}$ is $1 \mathrm{ppm}$ and $\mathrm{Zn}$ is $100 \mathrm{ppm}$. The threshold for $\mathrm{Pb}$ metal content that can be consumed according to Badan Standardisasi Indonesia (2009) is $0.5 \mathrm{ppm}$ and according to FAO (2015) is $0.1 \mathrm{ppm}$; hence, soybeans fertilized with SBE and DBE fillers are safe and can be consumed. 
Table 6. The content of $\mathrm{Ag}, \mathrm{Cu}, \mathrm{Cr}, \mathrm{Pb}$ and $\mathrm{Zn}$ in the kernel soybean

\begin{tabular}{cccccc}
\hline \multirow{2}{*}{ Treatment } & \multicolumn{5}{c}{ Heavy metal content in the kernel soybean } \\
\cline { 2 - 6 } & $\mathrm{Ag}(\mathrm{ppm})$ & $\mathrm{Cu}(\mathrm{ppm})$ & $\mathrm{Cr}(\mathrm{ppm})$ & $\mathrm{Pb}(\mathrm{ppm})$ & $\mathrm{Zn}(\mathrm{ppm})$ \\
\hline NPK + clay mineral 10\% & 0.42 & 11.39 & $0.53 \mathrm{ab}$ & $0.01 \mathrm{a}$ & $34.50 \mathrm{~b}$ \\
NPK + clay mineral 5\% + SBE 5\% & 0.20 & 12.44 & $0.68 \mathrm{a}$ & $0.01 \mathrm{a}$ & $48.71 \mathrm{a}$ \\
NPK + clay mineral 5\% + DBE 5\% & 0.20 & 11.21 & $0.23 \mathrm{~b}$ & $0.01 \mathrm{~b}$ & $35.28 \mathrm{~b}$ \\
\hline CV $(\%)$ & 23.04 & 2.83 & 7.93 & 0.00 & 2.26 \\
\hline
\end{tabular}

Note: The number followed by the different letters in the same column showed significant difference according to $\operatorname{LSD} 5 \%$.

Based on Table 7, leaf area had significantly positive correlation with total dry weight crop. The leaves are the site of photosynthesis and assimilation of plants. This shows that the plants with high leaf area will produce a large dry weight. From the high leaf area, plants will accumulate formed assimilation which is used as food reserves stored in economic storage organs. Crop pod weight had significantly positive correlation with crop seed weight and crop seed weight had a very significantly positive correlation with weight of 100 seeds (Table 7). Photosynthesis and nutrients become the most important source for the weight of seed yield during the seed filling period. Seed weight is related to source and sink capacity. A large source if not allowed by a large sink, the seed weight will be low and vice versa (Sutoro et al., 2008).

Table 7. Correlation matrix between growth parameters and yield of soybean

\begin{tabular}{cccccccc}
\hline Variable & $\mathrm{A}$ & $\mathrm{B}$ & $\mathrm{C}$ & $\mathrm{D}$ & $\mathrm{E}$ & $\mathrm{F}$ & $\mathrm{G}$ \\
\hline $\mathrm{A}$ & & & & & & & \\
$\mathrm{B}$ & $0.76^{*}$ & & & & & & \\
$\mathrm{C}$ & -0.13 & -0.08 & & & & \\
$\mathrm{D}$ & -0.59 & -0.36 & 0.23 & & & \\
$\mathrm{E}$ & -0.65 & -0.46 & 0.13 & 0.58 & & \\
F & -0.59 & -0.29 & -0.23 & 0.51 & $0.78^{*}$ & & \\
G & -0.36 & -0.25 & -0.52 & 0.10 & 0.57 & $0.86^{* *}$ & \\
\hline
\end{tabular}

Note: $*$ = Significant; $* *=$ Very significant; $\mathrm{A}=$ Leaf area; $\mathrm{B}=$ Total dry weight; $\mathrm{C}=$ Plant height $7 \mathrm{WAP} ; \mathrm{D}=$ Number of crop pods; $\mathrm{E}=$ Crop pod weight; $\mathrm{F}=$ Crop seed weight; $\mathrm{G}=$ Weight of 100 seeds

Based on observations of plant growth parameters such as plant height, leaf area and dry weight of plants, that NPK fertilization with $5 \%$ clay mineral $+5 \%$ SBE filler and NPK fertilization with $5 \%$ clay mineral $+5 \%$ DBE has the same effect as NPK fertilization with $10 \%$ clay mineral filler. For yield parameters such as number of planting pods, weight of planting pods, weight of planting seeds and dry weight of 100 seeds, NPK fertilized plants with $5 \%$ clay mineral $+5 \%$ SBE filler and NPK fertilization with 5\% clay mineral $+5 \%$ DBE filler has the same effect as NPK fertilization with $10 \%$ clay mineral filler. This indicates that SBE and DBE can be used as substitutes for some components of clay mineral filler in NPK fertilizer production and does not interfere with the growth and yield of soybean plants.

\section{CONCLUSIONS}

NPK fertilization with $5 \%$ clay mineral $+5 \%$ SBE filler and NPK with 5\% clay mineral $+5 \%$ DBE filler have the same effect as NPK fertilization with $10 \%$ clay mineral filler on leaf area, total dry weight, plant height, yield of plant and its use does not pollute the environment and human health. So it can be used as a partial replacement for clay mineral in the production of NPK fertilizer.

\section{ACKNOWLEDGEMENTS}

The authors thank Wilmar International Ltd for funding this research. 


\section{REFERENCES}

Adileksana, C., Yudono, P., Purwanto, B. H., \& Wijoyo, R. B. (2020). The growth performance of oil palm seedlings in prenursery and main nursery stages as a response to the substitution of NPK compound fertilizer and organic fertilizer. Caraka Tani: Journal of Sustainable Agriculture, 35(1), 89-97. https:// doi.org/10.20961/carakatani.v35i1.33884

Ahmad, P., Abd Allah, E. F., Hashem, A., Sarwat, M., \& Gucel, S. (2016). Erratum to: exogenous application of selenium mitigates cadmium toxicity in Brassica juncea L. (czern \& cross) by up-regulating antioxidative system and secondary metabolites $(j$ plant growth regul, 10.1007/s00344-016-9592-3). Journal of Plant Growth Regulation, 35(4), 951. https:// doi.org/10.1007/s00344-016-9632-z

Amanullah, A. (2015). Specific leaf area and specific leaf weight in small grain crops wheat, rye, barley, and oats differ at various growth stages and NPK source. Journal of Plant Nutrition, 38(11), 1694-1708. https://doi.org/ 10.1080/01904167.2015.1017051

Badan Standardisasi Indonesia. (2009). Batas maksimum cemaran logam berat dalam pangan. Standar Nasional Indonesia, 17. Retrieved from https://sertifikasibbia.com/ upload/logam_berat.pdf

Beshara, A., \& Cheeseman, C. R. (2014). Reuse of spent bleaching earth by polymerisation of residual organics. Waste Management, 34(10), 1770-1774. https://doi.org/10.1016/j.wasman. 2014.04.021

Boey, P. L., Saleh, M. I., Sapawe, N., Ganesan, S., Maniam, G. P., \& Ali, D. M. H. (2011). Pyrolysis of residual palm oil in spent bleaching clay by modified tubular furnace and analysis of the products by GC-MS. Journal of Analytical and Applied Pyrolysis, 91(1), 199-204. https://doi.org/10.1016/j.jaap. 2011.02.010

Eliche-Quesada, D., \& Corpas-Iglesias, F. A. (2014). Utilisation of spent filtration earth or spent bleaching earth from the oil refinery industry in clay products. Ceramics International, 40(10 Part B), $16677-$ 16687. https://doi.org/10.1016/j.ceramint.20 14.08.030
Embrandiri, A., Singh, R. P., Ibrahim, H. M., \& Ramli, A. A. (2012). Land application of biomass residue generated from palm oil processing: Its potential benefits and threats. Environmentalist, 32(1), 111-117. https://doi. org/10.1007/s10669-011-9367-0

Ermawati, T., \& Saptia, Y. (2013). Kinerja ekspor minyak sawit Indonesia. Buletin Ilmiah Litbang Perdagangan, 7(2), 129-147. Retrieved from http://jurnal.kemendag.go.id/ bilp/article/view/104/69

Eviati, \& Sulaeman. (2009). Analisis kimia tanah, tanaman, air, dan pupuk (Petunjuk T; B.H. Prasetyo, D. Santoso, \& L. R. W, eds.). Retrieved from http://balittanah.litbang.deptan .go.id

Fahmi, A. S., Gumbira-Sa'id, E., \& Suryani, A. (2014). Biodiesel production from residual palm oil contained in spent bleaching earth by in situ trans-esterification. EnvironmentAsia, 7(1), 104-111. Retrieved from http://www. thaiscience.info/journals/Article/ENVA/1093 3764.pdf

FAO. (2015). General standard for contaminants and toxins in food and feed (Codex Stan 1931995). 51(2), 39-54. Retrieved from http:// www.fao.org/input/download/standards/17/C XS_193e_2015.pdf

Fernando, D. R., Marshall, A. T., Forster, P. I., Hoebee, S. E., \& Siegele, R. (2013). Multiple metal accumulation within a manganesespecific genus. American Journal of Botany, 100(4), 690-700. https://doi.org/10.3732/ajb. 1200545

Gardner, F. P., Pearce, R. B., \& Mitchell, R. L. (2008). Fisiologi tanaman budidaya. Jakarta: UI Press.

Hanum, C. (2010). Pertumbuhan dan hasil kedelai yang diasosiasikan dengan rhizobium pada zona iklim kering e (klasifikasi oldeman). Bionatura - Jurnal Ilmu-Ilmu Hayati Dan Fisik, 12(3), 176-183. Retrieved from http:// jurnal.unpad.ac.id/bionatura/article/download/ $7692 / 3561$

Hussin, F., Aroua, M. K., \& Daud, W. M. A. W. (2011). Textural characteristics, surface chemistry and activation of bleaching earth: A review. Chemical Engineering Journal, 170(1), 90-106. https://doi.org/10.1016/j.cej. 


\subsubsection{5}

Jati, R. I., Tohari, T., \& Suryanto, P. (2017). The optimum dose of nitrogen, phosporus, and potassium to improve soybean (Glycine max (L) Merr) productivity on kayu putih (Melaleuca cajuputi) stands. Ilmu Pertanian (Agricultural Science), 2(2), 56-63. https:// doi.org/10.22146/ipas.17991

Kamilah, H., Al-Gheethi, A., Yang, T. A., \& Sudesh, K. (2018). The use of palm oil-based waste cooking oil to enhance the production of polyhydroxybutyrate $[\mathrm{p}(3 \mathrm{hb})]$ by cupriavidus necator h16 strain. Arabian Journal for Science and Engineering, 43(7), 3453-3463. https://doi.org/10.1007/s13369-018-3118-1

Kastono, D. (2005). Tanggapan Pertumbuhan dan hasil kedelai hitam terhadap penggunaan pupuk organik dan biopestisida gulma siam (Chromolaena odorata). Ilmu Pertanian, 12(2), 103-116. Retrieved from http://i-lib. ugm.ac.id/jurnal/download.php?dataId $=7448$

Kheang, L. S., Foon, C. S., May, C. Y., \& Ngan, M. A. (2006). A study of residual oils recovered from spent bleaching earth: Their characteristics and applications. American Journal of Applied Sciences, 3(10), 20632067. https://doi.org/10.3844/ajassp.2006.206 3.2075

Loh, S. K., Cheong, K. Y., Choo, Y. M., \& Salimon, J. (2015). Formulation and optimisation of spent bleaching earth-based bio organic fertiliser. Journal of Oil Palm Research, 27(1), 57-66. Retrieved from http://jopr.mpob.gov.my/wp-content/uploads/ 2015/03/Pages-from-JOPR271_web-61.pdf

Loh, S. K., James, S., Ngatiman, M., Cheong, K. Y., Choo, Y. M., \& Lim, W. S. (2013). Enhancement of palm oil refinery waste Spent bleaching earth (SBE) into bio organic fertilizer and their effects on crop biomass growth. Industrial Crops and Products, 49, 775-781. https://doi.org/10.1016/j.indcrop.20 13.06.016

Mulyadi, A. (2012). Pengaruh pemberian legin, pupuk npk (15:15:15) dan urea pada tanah gambut terhadap kandungan $n, p$ total pucuk dan bintil akar kedelai (Glycine $\max (\mathrm{L})$ Merr). Kaunia: Integration and Interconnection Islam and Science, 8(1), 21-29. Retrieved from http://ejournal.uin-suka.ac.id/saintek/kau nia/article/view/1038

Ng, W. K., Koh, C. B., \& Din, Z. B. (2006). Palm oil-laden spent bleaching clay as a substitute for marine fish oil in the diets of Nile tilapia, Oreochromis niloticus. Aquaculture Nutrition, 12(6), 459-468. https://doi.org/10.1111/j.13 65-2095.2006.00449.x

Ofori-Boateng, C., \& Lee, K. T. (2013). Sustainable utilization of oil palm wastes for bioactive phytochemicals for the benefit of the oil palm and nutraceutical industries. Phytochemistry Reviews, 12(1), 173-190. https://doi.org/10.1007/s11101-013-9270-z

Park, E. Y., Kato, A., \& Ming, H. (2004). Utilization of waste activated bleaching earth containing palm oil in riboflavin production by Ashbya gossypii. JAOCS, Journal of the American Oil Chemists' Society, 81(1), 57-62. https://doi.org/10.1007/s11746-004-0857-z

Permanasari, I., Irfan, M., \& Abizar. (2014). Pertumbuhan dan hasil kedelai (Glycine max (L.) Merill) dengan pemberian rhizobium dan pupuk urea pada media gambut. Jurnal Agroteknologi, 5(1), 29-34. Retrieved from http://ejournal.uin-suska.ac.id/index.php/agro teknologi/article/view/1145

Purba, R. S., Irwan, S. N. R., \& Putra, E. T. S. (2019). The effect of spent bleaching earth filler-based npk fertilization on proline, growth and yield of maize. Caraka Tani: Journal of Sustainable Agriculture, 35(1), 4453. https://doi.org/10.20961/carakatani.v35i1. 34166

PUSDATIN KEMENTAN. (2018). Outlook kedelai komoditas pertanian subsektor tanaman pangan. Retrieved from http:// epublikasi.pertanian.go.id/download/file/523outlook-kedelai-2018

Putra, F. P., Yudono, P., \& Waluyo, S. (2017). Growth and yield of upland rice under intercropping system with soybean in sandy coastal area. Ilmu Pertanian (Agricultural Science), 2(3), 130. https://doi.org/10.22146/ ipas.25215

Rai, V., Vajpayee, P., Singh, S. N., \& Mehrotra, S. (2004). Effect of chromium accumulation on photosynthetic pigments, oxidative stress defense system, nitrate reduction, proline level 
and eugenol content of Ocimum tenuiflorum L. Plant Science, 167(5), 1159-1169. https:// doi.org/10.1016/j.plantsci.2004.06.016

Rauf, A., Merle Shepard, B., \& Johnson, M. W. (2000). Leafminers in vegetables, ornamental plants and weeds in Indonesia: Surveys of host crops, species composition and parasitoids. International Journal of Pest Management, 46(4), 257-266. https://doi.org/10.1080/0967 0870050206028

Rosi, A., Roviq, M., \& Nihayati, E. (2018). Pengaruh dosis pupuk NPK pada pertumbuhan dan hasil tiga varietas kedelai (Glycine max (L.) Merr.). Jurnal Produksi Tanaman, 6(10), 2445-2452. Retrieved from http://protan. studentjournal.ub.ac.id/index.php/protan/articl e/download/927/947

Soda, W., Noble, A. D., Suzuki, S., Simmons, R., Sindhusen, L. A., \& Bhuthorndharaj, S. (2006). Co-composting of acid waste bentonites and their effects on soil properties and crop biomass. Journal of Environmental Quality, 35(6), 2293-2301. https://doi.org/ $10.2134 /$ jeq2005.0455

Suhartini, S., Hidayat, N., \& Wijaya, S. (2011). Physical properties characterization of fuel briquette made from spent bleaching earth. Biomass and Bioenergy, 35(10), 42094214. https://doi.org/10.1016/j.biombioe.2011 .07 .002

Sumarno, A., Widodo, E., Nugroho, A., Triastuti, \& Suryanegara, L. (2017). Pemanfaatan limbah spent bleaching earth (sbe) dari industri pengolahan minyak kelapa sawit pada aplikasi bata beton. Seminar Lignoselulosa, 3(85), 4044. Retrieved from https://www.researchgate. net/profile/Agung_Sumarno/publication/3226 96914_Pemanfaatan_Limbah_Spent_Bleachi ng_Earth_SBE_dari_Industri_Pengolahan_Mi nyak_Kelapa_Sawit_pada_Aplikasi_Bata_Bet on/links/5a699f9f0f7e9b01f3ed99e1/Pemanfa atan-Limbah-Spent-Bleaching-E

Sutoro, Dewi, N., \& Setyowati, M. (2008). Hubungan sifat morfofisiologis tanaman dengan hasil kedelai. Jurnal Penelitian Pertanian Tanaman Pangan, 27(3), 185-190. Retrieved from https://adoc.tips/download/ hubungan-sifat-morfofisiologis-tanamandengan-hasil-kedelai-.html

Tunçtürk, M., Tunçtürk, R., Yildirim, B., \& Çiftçi, V. (2011). Effect of salinity stress on plant fresh weight and nutrient composition of some canola (Brassica napus L.) cultivars. African Journal of Biotechnology, 10(10), 1827-1832. https://doi.org/10.5897/AJB10.16 18

Widyaswari, E., Santosa, M., \& Maghfoer, M. D. (2017). Analisis pertumbuhan dua varietas tanaman padi (Oryza sativa L.) pada berbagai perlakuan pemupukan. Biotropika - Journal of Tropical Biology, 5(3), 73-77. https://doi.org/ 10.21776/ub.biotropika.2017.005.03.2

Zhuang, P., Li, Z. A., Zou, B., Xia, H. P., \& Wang, G. (2013). Heavy metal contamination in soil and soybean near the Dabaoshan Mine, South China. Pedosphere, 23(3), 298-304. https:// doi.org/10.1016/S1002-0160(13)60019-3 